\title{
Enzyme-MXene Nanosheets: Fabrication and Application in Electrochemical Detection of $\mathrm{H}_{2} \mathrm{O}_{2}$
}

\begin{abstract}
MA Bao-Kai ${ }^{1,2,3}$, LI Mian ${ }^{3}$, CHEONG Ling-Zhi ${ }^{2}$, WENG Xin-Chu ${ }^{1}$, SHEN Cai ${ }^{3}$, HUANG Qing ${ }^{3}$
(1. School of Life and Sciences, Shanghai University, Shanghai 200444, China; 2. Department of Food Science and Engineering, College of Food and Pharmaceutical Sciences, Ningbo University, Ningbo 315211, China; 3. Institute of Materials Technology \& Engineering, Chinese Academy of Sciences, Ningbo 315201, China)

Abstract: Two-dimensional MXene nanosheets with vertical junction structure was employed for easy immobilization of horse radish peroxidase enzymes to fabricate the electrochemical hydrogen peroxide $\left(\mathrm{H}_{2} \mathrm{O}_{2}\right)$ biosensor. The synthesized MXene nanosheets exhibited large specific area, excellent electronic conductivity and good dispersion in aqueous phase. Horse Radish Peroxidase (HRP) enzymes molecules immobilized on MXene/chitosan/GCE electrode demonstrated good electrocatalytic activity toward reduction of $\mathrm{H}_{2} \mathrm{O}_{2}$. The fabricated HRP@MXene/chitosan/GCE biosensor exhibited a wide linear range from 5 to $1650 \mu \mathrm{mol} \cdot \mathrm{L}^{-1}$, a limit of detection of $0.74 \mu \mathrm{mol} \cdot \mathrm{L}^{-1}$ and $\mathrm{good} \mathrm{op}$ eration stability. The fabricated biosensor was successfully employed for detection of trace level of $\mathrm{H}_{2} \mathrm{O}_{2}$ in both solid and liquid food.
\end{abstract}

Key words: horse radish peroxidase; MXene nanosheets; biosensor; hydrogen peroxide

Hydrogen peroxide $\left(\mathrm{H}_{2} \mathrm{O}_{2}\right)$ is widely used as antimicrobial, oxidizing, reducing and bleaching agents in many fields including pharmaceutical, medical, textile, paper, and food processing ${ }^{[1]}$. The United States Food and Drug Administration (USFDA) has affirmed the Generally Recognized As Safe (GRAS) status of $\mathrm{H}_{2} \mathrm{O}_{2}$ for use in food with a maximum permitted concentration in specified foods and residual must be removed by appropriate processing ${ }^{[2]}$. Excessive amount of $\mathrm{H}_{2} \mathrm{O}_{2}$ has been reported to have a destructive impact on central nervous system of human body and can result in oxidative stress which is associated with many diseases including neurodegenerative disorders, diabetes, atherosclerosis and cancers ${ }^{[3-4]}$. Therefore, monitoring $\mathrm{H}_{2} \mathrm{O}_{2}$ residual in food is of practical significance to both academic and industry. To date, a variety of techniques including fluorometry ${ }^{[5]}$, spectrophotometry ${ }^{[6-7]}$ and electrochemistry $^{[8-9]}$ have been developed for detection and quantification of $\mathrm{H}_{2} \mathrm{O}_{2}$.

Electrochemical biosensing technique has generated much interest due to its advantages of simple instrumentation, easy miniaturization, high sensitivity and selectivity, as well as rapid response ${ }^{[10]}$. At present, very few electrochemical biosensors reached practical application and commercialization mainly due to its inconsistent operational stability ${ }^{[11]}$. The sensitivity, selectivity and operational stability of electrochemical biosensors are strongly dependent on structure and properties of electrode materials and enzyme immobilization matrixes ${ }^{[1,12-13]}$.

Two-dimensional (2D) transition metal carbides, nitrides and carbonitrides (MXene) are produced by etching layers of sp elements (specifically groups 13 and 14) from their corresponding three-dimensional (3D) MAX phases which correspond to the general formula $\mathrm{M}_{n+1} \mathrm{AX}_{n}$ $(n=1,2,3)$ where $\mathrm{M}$ represents early d-block transition metals (Ti, Sc, V, Cr, Ta, Nb, Zr, Mo, Hf), A represents main group sp elements and $\mathrm{X}$ is either $\mathrm{C}$ or $\mathrm{N}$ atom ${ }^{[14-15]}$. MXenes have generated a lot of interest due to their hydrophilic surfaces, good structural and chemical stabilities, excellent electrical conductivities, and environmentfriendly characteristics ${ }^{[16-17]}$. As MXene surfaces can be used for easy immobilization of enzymes/protein to achieve accelerated reaction kinetics, low detection limits, high sensitivity and selectivity. So it is suitable for use as highly sensitive and selective detection platform for biosensing applications ${ }^{[18-21]}$. Understanding of the sensitivity, selectivity and long term operational stability of MXene electrochemical biosensors are important for application of MXene biosensors for various purposes.

Present study aims to fabricate a horse radish peroxidase@MXene electrochemical biosensor for detection of

Received date: 2019-03-28; Revised date: 2019-04-16

Foundation item: Ningbo University(421401560); National Natural Science Foundation of China $(21706137,21671195)$

Biography: MA Bao-Kai (1992-), male, Master candidate. E-mail: mabaokai@nimte.ac.cn 马保凯(1992-), 男, 硕士研究生. E-mail: mabaokai@nimte.ac.cn

Corresponding author: CHEONG Ling-Zhi, associate professor. E-mail: lingzhicheong@yahoo.com 张绫芷, 副教授. E-mail: lingzhicheong@yahoo.com 
$\mathrm{H}_{2} \mathrm{O}_{2}$ in food. HRP, a heme-containing enzyme, has been widely used to catalyze oxidation of a wide variety of substrates including hydrogen peroxide ${ }^{[22-23]}$. MXene with vertical junction structure in which MXene sheets are perpendicular to the plane of graphite has been demonstrated to have good electromagnetic absorption properties $^{[24]}$. We proposed that this vertical junction structure will improve HRP immobilization and demonstrate good electron transfer properties which made it a suitable enzyme immobilization matrix for fabrication of $\mathrm{H}_{2} \mathrm{O}_{2}$ electrochemical biosensor. We synthesized and characterized MXene using X-ray powder diffraction (XRD), Fourier transform infared spectroscopy (FT-IR) and scanning electron microscopy (SEM). MXene was then used as HRP immobilization matrixes to fabricate HRP@MXene/ chitosan/GCE biosensor. Electrochemical behavior of the fabricated HRP@MXene/chitosan/GCE biosensor was investigated and optimized using cyclic voltammetry (CV) and different pulse voltammetry (DPV). Amperometric method was used to detect concentration of $\mathrm{H}_{2} \mathrm{O}_{2}$ in real food samples. Selectivity and storage stability of the HRP@MXene/chitosan/GCE were also elucidated.

\section{Experimental}

\subsection{Materials and chemicals}

Horseradish peroxide (HRP, activity units $\cdot \mathrm{mg}^{-1}$ ) was purchased from Sigma Aldrich. Natural flake graphite $(48 \mu \mathrm{m})$, Ti powders $(48 \mu \mathrm{m}$, purity of $99.9 \%)$, Al powders $(48 \mu \mathrm{m}$, purity of $99.9 \%)$, hydrogen peroxide solution (30wt\%), hydroquinone (HQ), chitosan (deacetylation $95 \%$ ), potassium chloride, acetic acid were obtained from Aladdin, China. Other reagents including $\mathrm{NaCl}, \mathrm{KCl}$, sodium hydroxide $(\mathrm{NaOH}), \mathrm{K}_{3}\left[\mathrm{Fe}(\mathrm{CN})_{6}\right], \mathrm{K}_{4}\left[\mathrm{Fe}(\mathrm{CN})_{6}\right]$. $3 \mathrm{H}_{2} \mathrm{O}$ were obtained from Sinoreagent, China. $0.1 \mathrm{~mol} \cdot \mathrm{L}^{-1}$ phosphate buffer solutions (PBS, pH 7.0) comprising $\mathrm{NaH}_{2} \mathrm{PO}_{4}$ and $\mathrm{Na}_{2} \mathrm{HPO}_{4}$ were used as electrolyte. All aqueous solutions were freshly prepared with ultra-pure water $(18 \mathrm{M} \Omega \cdot \mathrm{cm})$.

\subsection{Synthesis of MXene (Graphite/TiC/Ti ${ }_{3} \mathrm{C}_{2}$ )}

$\mathrm{G}$ (graphite)/TiC/ $/ \mathrm{Ti}_{3} \mathrm{AlC}_{2}$ were fabricated according to a previously reported method with slight modifications ${ }^{[24]}$. Graphite powder $(48 \mu \mathrm{m})$, Ti powders $(48 \mu \mathrm{m}$, purity of $99.9 \%$ ), Al powders (48 $\mu \mathrm{m}$, purity of $99.9 \%), \mathrm{NaCl}$ and $\mathrm{KCl}$ were mixed at a molar ratio of $4: 4: 1: 10: 10$, placed in alumina crucible and packaged in a tube furnace. The tube furnace was heated to $800{ }^{\circ} \mathrm{C}$ at a heating rate of $4{ }^{\circ} \mathrm{C} \cdot \mathrm{min}^{-1}$ under argon protection and kept for $300 \mathrm{~min}$. Following that, the mixtures were heated to $1100{ }^{\circ} \mathrm{C}$ at a heating rate of $4{ }^{\circ} \mathrm{C} \cdot \mathrm{min}^{-1}$, kept for $180 \mathrm{~min}$ and finally cooled to room temperature at a cooling rate of $4{ }^{\circ} \mathrm{C} \cdot \mathrm{min}^{-1}$. The resulting product $\left(\mathrm{G} / \mathrm{TiC} / \mathrm{Ti}_{3} \mathrm{AlC}_{2}\right)$ was washed by deionized water to remove salts and dried at $80{ }^{\circ} \mathrm{C} . \mathrm{G} / \mathrm{TiC} / \mathrm{Ti}_{3} \mathrm{C}_{2}$ were obtained by etching process using $\mathrm{HF}$ to remove the $\mathrm{Al}$ atoms.

\subsection{Characterization of MXene}

MXene was characterized using XRD, FT-IR and SEM. $\mathrm{XRD}$ analysis were conducted at room temperature using Bruker D8 Discover XRD (Cu radiation, $\lambda=0.1540596 \mathrm{~nm}$ ) over the $2 \theta$ range of $5^{\circ} \sim 70^{\circ}$ at room temperature. FT-IR spectra was obtained in the range of 500 to $4000 \mathrm{~cm}^{-1}$ by using a Fourier-transform infrared (FT-IR) spectroscopy (Nicolet 6700, Thermo, USA).

The microstructures of the powders were examined by a field emission scanning electron microscopy (FEI Quanta FEG 250) equipped with an EDS system and a TEM instrument (FEI Tecnai F20).

\subsection{Fabrication of the HRP@MXene/chitosan/ GCE biosensor}

Fabrication of the HRP@MXene electrochemical biosensor is illustrated in Fig. 1. Glassy carbon electrodes (GCE, $3 \mathrm{~mm}$ ) was firstly polished using $\mathrm{Al}_{2} \mathrm{O}_{3}(1.0,0.3$, $0.05 \mu \mathrm{m})$, cleaned by ethanol and water for three times, and finally dried under gentle $\mathrm{N}_{2}$ stream. Ten microliter of HRP solution [10 $\mathrm{mg} \cdot \mathrm{mL}^{-1}$, PBS $\left(0.1 \mathrm{~mol} \cdot \mathrm{L}^{-1}, \mathrm{pH} 6.0\right)$ ] and $20 \mu \mathrm{L}$ of MXene aqueous solution $\left(5 \mathrm{mg} \cdot \mathrm{mL}^{-1}\right)$ were mixed and shaked at $200 \mathrm{r} \cdot \mathrm{min}^{-1}$ for $10 \mathrm{~h}$ at low temperature.

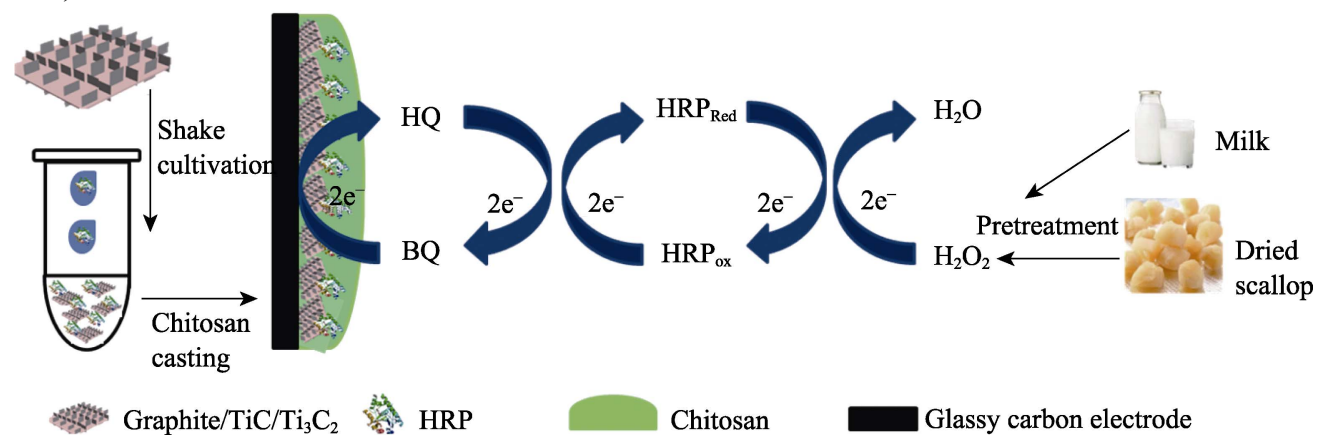

Fig. 1 Schematic illustration for fabrication of HRP@MXene (Graphite/TiC/ $\left./ \mathrm{Ti}_{3} \mathrm{C}_{2}\right) / \mathrm{chitosan} / \mathrm{GCE}$ and $\mathrm{H}_{2} \mathrm{O}_{2}$ sensing principle of HRP@MXene/chitosan/GCE 
Following that, $10 \mu \mathrm{L}$ chitosan solution $\left(6 \mathrm{mg} \cdot \mathrm{mL}^{-1}\right.$, adjusted to $\mathrm{pH} 6.0$ by $\left.10 \mathrm{mg} \cdot \mathrm{mL}^{-1} \mathrm{NaOH}\right)$ was added to the mixture and vibrated for $3 \mathrm{~min}$. Chitosan solution has been previously reported to be positively charged and have good electrical conductivity at $\mathrm{pH} 6.0$ due to the protonation of amino groups ${ }^{[8,25]}$. As MXenes synthesized in present study is negatively charged due to the abundance of hydroxyl or fluoride groups, it could be well adhered in chitosan solution via Coulomb effect and formed a unique film on the surface of $\mathrm{GCE}^{[26]} .5 \mu \mathrm{L}$ of the resultant HRP@MXene/chitosan was dropwisely casted onto the surface of a freshly polished GCE. The prepared electrodes (HRP@MXene/chitosan/GCE) were dried and stored in $0.05 \mathrm{~mol} \cdot \mathrm{L}^{-1} \mathrm{PBS}(\mathrm{pH} 7.5)$ in a refrigerator $\left(4{ }^{\circ} \mathrm{C}\right)$ prior to usage.

\subsection{Electrochemical behavior of the HRP@ MXene/chitosan/GCE biosensor}

All electrochemical experiments were carried out using CHI760E electrochemical workstation (Chenhua, Shanghai) with GCE as working electrode, platinum wire as counter electrode and saturated calomel electrode (SCE) as reference electrode. The electrochemical impedance spectroscopy (EIS) and cyclic voltammograms (CVs) of electrodes fabricated using chitosan of different $\mathrm{pH}$ was conducted in $\mathrm{N}_{2}$-saturated $0.1 \mathrm{~mol} \cdot \mathrm{L}^{-1} \mathrm{KCl}$ solution containing $5.0 \mathrm{mmol} \cdot \mathrm{L}^{-1} \mathrm{Fe}(\mathrm{CN})_{6}^{3-/ 4-}$ at open circuit potential in the frequency range from $0.1 \mathrm{~Hz}$ to $10^{5} \mathrm{~Hz}$ with the amplitude $5 \mathrm{mV}$. The EIS data were analyzed using ZVIEW software.

\subsection{Electrochemical biosensing of $\mathrm{H}_{2} \mathrm{O}_{2}$ by HRP@MXene/chitosan/GCE biosensor}

CVs were carried out in $\mathrm{N}_{2}$-saturated $0.1 \mathrm{~mol} \cdot \mathrm{L}^{-1} \mathrm{PBS}$ $(\mathrm{pH} 7.5)$ in the presence of $2.0 \mathrm{mmol} \cdot \mathrm{L}^{-1} \mathrm{H}_{2} \mathrm{O}_{2}$ and $1 \mathrm{mmol} \cdot \mathrm{L}^{-1} \mathrm{HQ}$ (dissolved in methanol) at a scanning rate of $50 \mathrm{mV} \cdot \mathrm{s}^{-1}$. Differential pulse voltammetry (DPV) was performed in $\mathrm{N}_{2}$-saturated $0.1 \mathrm{~mol} \cdot \mathrm{L}^{-1} \mathrm{PBS}(\mathrm{pH} 7.5$ ) containing $2 \mathrm{mmol} \cdot \mathrm{L}^{-1} \quad \mathrm{H}_{2} \mathrm{O}_{2}$ and $1 \mathrm{mmol} \cdot \mathrm{L}^{-1} \mathrm{HQ}$ (dissolved in methanol) with amplitude of $5 \mathrm{mV}$ and pulse width of $0.2 \mathrm{~s}$ after five times of $\mathrm{CV}$ at a scanning rate of $50 \mathrm{mV} \cdot \mathrm{s}^{-1}$ ranging from $0.8 \mathrm{~V}$ to $-0.8 \mathrm{~V}$. The effects of electrolyte PBS buffer pH (5.5 to 8 ) and the concentration of MXene were evaluated and optimized in terms of CV and DPV signal.

\subsection{Electrochemical detection of $\mathrm{H}_{2} \mathrm{O}_{2}$ in spiked dried scallop and milk}

Amperometric current-time curves for $\mathrm{H}_{2} \mathrm{O}_{2}$ were carried out to construct a calibration curve of current response at different $\mathrm{H}_{2} \mathrm{O}_{2}$ concentration. Measurements were performed in $10 \mathrm{~mL}$ of stirring $0.1 \mathrm{~mol} \cdot \mathrm{L}^{-1} \mathrm{PBS}(\mathrm{pH}$ $7.5)$ in the presence of $1 \mathrm{mmol} \cdot \mathrm{L}^{-1} \mathrm{HQ}$ with successive addition of $\mathrm{H}_{2} \mathrm{O}_{2}$ at room temperature under an applied peak potential value of $-0.1 \mathrm{~V}$. LOD was determined according to the following equation:

$$
\mathrm{LOD}=3 \mathrm{SD} / \mathrm{K}
$$

whereby SD refers to the standard deviation of the control measurement, and $\mathrm{K}$ refers to slope of the calibration curve.

Milk and dried scallop were chosen as model of liquid and solid food. Milk sample was used directly for $\mathrm{H}_{2} \mathrm{O}_{2}$ detection. Dried scallop was pre-treated according to the following procedure to extract $\mathrm{H}_{2} \mathrm{O}_{2}$ residual. Briefly, $2 \mathrm{~g}$ of dried scallop was immersed in $5 \mathrm{~mL}$ of $\mathrm{H}_{2} \mathrm{O}_{2}$ aqueous solution (3\%) for $1 \mathrm{~h}$. Following that, the scallop was immersed in $5 \mathrm{~mL}$ of water for $0.5 \mathrm{~h}$ to extract $\mathrm{H}_{2} \mathrm{O}_{2}$ residue. $\mathrm{H}_{2} \mathrm{O}_{2}$ concentration in spiked dried scallop test solution and milk solution $\left(12.5,50\right.$ and $125 \mu \mathrm{mol} \cdot \mathrm{L}^{-1}$ $\mathrm{H}_{2} \mathrm{O}_{2}$ ) were detected using the amperometric currenttime curves for $\mathrm{H}_{2} \mathrm{O}_{2}$. Recovery of the HRP@MXene/ Chitosan/GCE was calculated.

\subsection{Selectivity of the biosensor}

Selectivity of the fabricated HRP@MXene/chitosan/ GCE biosensor was evaluated using potentially interfering substances including uric acid, glucose and ascorbic acid [ $100 \mu \mathrm{mol} \cdot \mathrm{L}^{-1}$ in $\left.0.1 \mathrm{~mol} \cdot \mathrm{L}^{-1} \mathrm{PBS}(\mathrm{pH} 7.5)\right]$.

\subsection{Storage stability of the biosensor}

Storage stability of the HRP@MXene/GCE was evaluated by monitoring reduction peak in $\mathrm{CVs}$ in $0.1 \mathrm{~mol} \cdot \mathrm{L}^{-1} \mathrm{PBS}$ with $1 \mathrm{mmol} \cdot \mathrm{L}^{-1} \mathrm{HQ}$ and $2 \mathrm{mmol} \cdot \mathrm{L}^{-1} \mathrm{H}_{2} \mathrm{O}_{2}$ during electrodes storage in $0.05 \mathrm{~mol} \cdot \mathrm{L}^{-1} \mathrm{PBS}$ at $4{ }^{\circ} \mathrm{C}$.

\section{Results and discussion}

\subsection{Characterization of the synthesized MXene and HRP@MXene}

XRD patterns of the synthesized MXene (G/TiC/ $\left./{ }_{3} \mathrm{C}_{2}\right)$ and $\mathrm{G} / \mathrm{TiC} / \mathrm{Ti}_{3} \mathrm{AlC}_{2}$ are showed in Fig. 2(A). G/TiC/Ti ${ }_{3} \mathrm{C}_{2}$ demonstrates a dominant phase of graphite (peak at $\sim 26^{\circ}$ ) and $\mathrm{TiC}$ (peaks at $35.9^{\circ}, 41.8^{\circ}$ ). This is in agreement with previously reported finding ${ }^{[24]}$. In addition, after $\mathrm{HF}$ etching, the peak at $39^{\circ}$ corresponded to the (104) plane of $\mathrm{Ti}_{3} \mathrm{AlC}_{2}$ disappears compared with the XRD pattern of $\mathrm{Ti}_{3} \mathrm{AlC}_{2}$ which indicates the elimination of $\mathrm{Al}$ during the $\mathrm{G} / \mathrm{TiC} / \mathrm{Ti}_{3} \mathrm{C}_{2}$ syntheses process.

As shown in Fig 2(B), FT-IR spectra of MXene do not display any absorption peaks from 3800 to $400 \mathrm{~cm}^{-1}$. Meanwhile, HRP demonstrates characteristic peaks at 2961, 1647, 1541, and $1080 \mathrm{~cm}^{-1}$. The amide I band (1700-1600 $\mathrm{cm}^{-1}$ ) can be assigned to the $\alpha$-helical conformation of the HRP; meanwhile, the amide II band can be assigned to the $\beta$-sheet structure of the $\mathrm{HRP}^{[3]}$. Following immobilization of HRP onto the two dimensional 

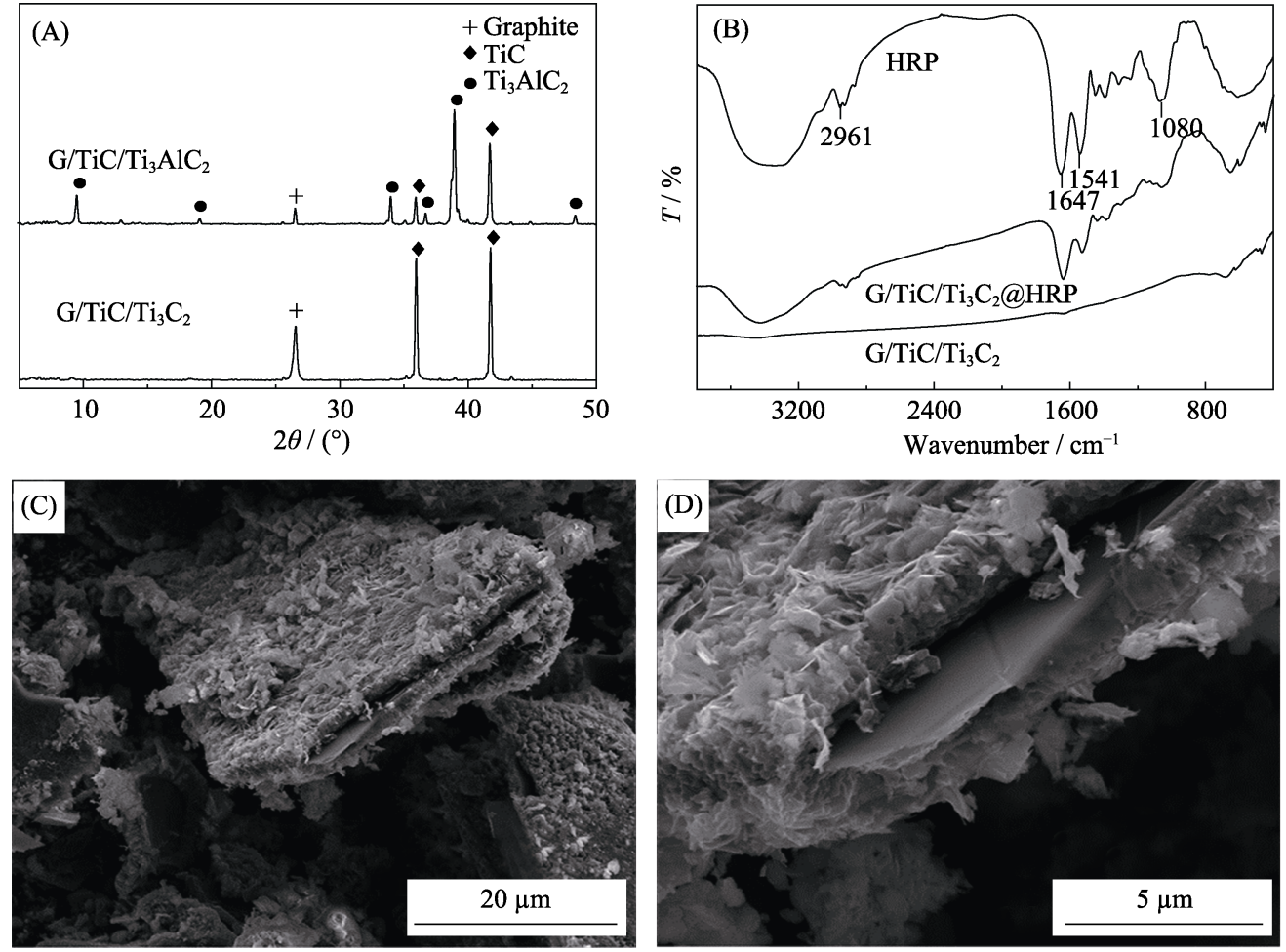

Fig. 2 XRD patterns of $\mathrm{G} / \mathrm{TiC} / \mathrm{Ti}_{3} \mathrm{AlC}_{2}$ and $\mathrm{G} / \mathrm{TiC} / \mathrm{Ti}_{3} \mathrm{C}_{2}(\mathrm{~A})$; FT-IR spectra of the MXene, HRP and HRP@MXene (B); SEM images of the MXene G/TiC (C) and $\mathrm{Ti}_{3} \mathrm{C}_{2}(\mathrm{D})$

MXene nanosheets, the major bands of HRP can be observed on the FT-IR spectra of HRP@MXene indicating successful immobilization process without any conformational change in the secondary structure of HRP.

SEM analysis shows a two dimensional multilayered structured of $\mathrm{Ti}_{3} \mathrm{C}_{2}(<1 \mu \mathrm{m})$ standing perpendicular to the plane of $\mathrm{G} / \mathrm{TiC}$ forming interfacial junctions (Fig. 1(C)). The multilayer $\mathrm{Ti}_{3} \mathrm{C}_{2}$ also demonstrated typical MXene morphology of two-dimension structure (Fig. 1(D)). This two-dimensional multilayered interfacial junctions structure provides a large specific surface area for efficient enzyme immobilization/entrapment.

\subsection{Electrochemical behavior of the fabricated GCE biosensor}

Chitosan, a natural film-forming agent, is commonly used in fabrication of enzyme electrodes. It is positively charged at $\mathrm{pH}<6.3$ due to protonation of amino groups ${ }^{[8,27]}$. At $\mathrm{pH}>6.3$, chitosan demonstrated decreased solubility in aqueous solution with the decline of adhesion. Fig. S1(A) shows the effects of $\mathrm{pH}$ of chitosan solution on charge transfer resistance $\left(R_{\mathrm{ct}}\right)$ of chitosan/GCE electrodes. $R_{\mathrm{ct}}$ was found to slightly increase with $\mathrm{pH}$ increasing from $\mathrm{pH} 5.0$ to 6.0. However, a dramatic increase in $R_{\mathrm{ct}}$ from $0.347 \mathrm{k} \Omega$ to $1.304 \mathrm{k} \Omega$ can be observed as $\mathrm{pH}$ of the chitosan solution increased from 6.0 to 6.5 and reached $4.663 \mathrm{k} \Omega$ at $\mathrm{pH} 7.0$.

In addition, according to Fig. S1(B), redox peaks current decreased with increased $\mathrm{pH}$, and peak separation $(\Delta E p)$ became bigger when $\mathrm{pH}$ from 6.0 to 7.0. The increasing $R_{\mathrm{ct}}$ reflected the degressive electrical conductivity of chitosan because of protonation of amino groups, and the increasing $\triangle E p$ indicated the declined ability of electronic transfer. Considering the film-forming and electrical conductivity of chitosan, in addition, HRP was reported to be most active at nearly neutral ${ }^{[28-29]}$, chitosan solution at $\mathrm{pH} 6.0$ was used in the fabrication of HRP@MXene/ chitosan/GCE biosensor. Fig. 3(A) shows the Nyquist plots of chitosan/GCE, MXene/chitosan/GCE and HRP@MXene/ chitosan/GCE. All three electrodes demonstrated the electron transfer- limited process in the high frequency area. Chitosan/GCE electrode had an $R_{\mathrm{ct}}$ value of $174.40 \Omega$. Incorporation of MXene onto the chitosan/GCE matrix resulted in a decreased $R_{\mathrm{ct}}$ value of MXene/chitosan/GCE to $52.88 \Omega$ indicating good electron transfer property of MXene from the redox probe of $\left[\mathrm{Fe}(\mathrm{CN})_{6}\right]^{3-/ 4-}$. Nevertheless, immobilization of HRP onto the MXene/chitosan/GCE matrix increase of the $R_{\mathrm{ct}}$ value of HRP@MXene/chitosan/ GCE to $542.60 \Omega$. Increasement of the $R_{\mathrm{ct}}$ value is mainly caused by steric hindrance, electrostatic interactions and partial blockage of interfacial electrons by enzyme molecules which has poor conductivity ${ }^{[10]}$. Cyclic voltammetry $(\mathrm{CV})$ for the different electrodes were carried out in $5.0 \mathrm{mmol} \cdot \mathrm{L}^{-1}$ $\mathrm{Fe}\left[(\mathrm{CN})_{6}\right]^{3-/ 4-}$ and $0.1 \mathrm{~mol} \cdot \mathrm{L}^{-1} \mathrm{KCl}$ (Fig. 3(B)). 

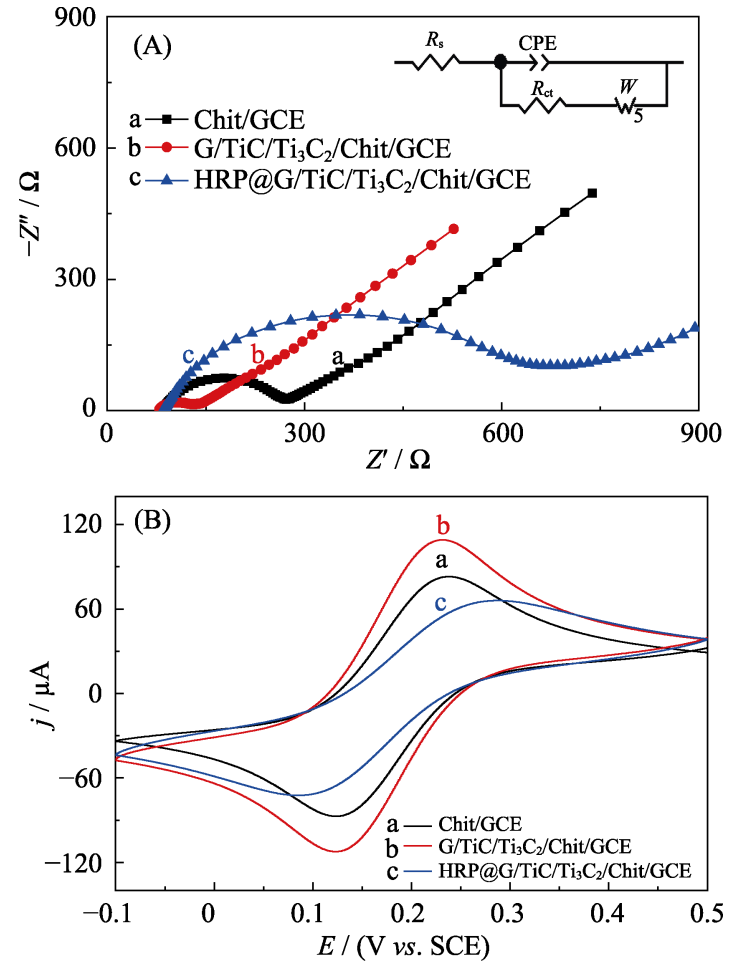

Fig. 3 EIS of Chit(chitosan)/GCE(a), MXene/Chit/GCE(b), HRP@MXene/Chit/GCE (c) electrodes cycled in $0.1 \mathrm{~mol} \cdot \mathrm{L}^{-1}$ $\mathrm{KCL}$ aqueous solution containing $5 \mathrm{mmol} \cdot \mathrm{L}^{-1}\left[\mathrm{Fe}(\mathrm{CN})_{6}\right]^{3-/ 4-}$ (A); CV curves of Chit/GCE (a), MXene/Chit/GCE (b), HRP@MXene/Chit/GCE (c) electrodes cycled in $0.1 \mathrm{~mol} \cdot \mathrm{L}^{-1}$ $\mathrm{KCL}$ aqueous solution containing $5 \mathrm{mmol} \cdot \mathrm{L}^{-1}\left[\mathrm{Fe}(\mathrm{CN})_{6}\right]^{3-/ 4-}$ : (potential window: $-0.1-0.5 \mathrm{~V} v s . \mathrm{SCE})(\mathrm{B})$

In comparison with Chitosan/GCE (curve a), MXene/ chitosan/GCE (curve b) demonstrated an increase in current response and similar $\Delta E p$ value (differences between anodic and cathodic peaks potential) indicating MXene is an excellent electric conducting material. Meanwhile, HRP@MXene/chitosan/GCE (curve c) demonstrated a decrease in current response and an increase in $\Delta E p$ value indicating HRP hindered the electron conductivity.

\subsection{Electrochemical biosensing of $\mathrm{H}_{2} \mathrm{O}_{2}$ by the biosensor}

Fig. 4 shows the CV of chitosan/GCE, MXene/chitosan/GCE, HRP@chitosan/GCE, and HRP@MXene/chitosan/ GCE electrodes obtained in $0.1 \mathrm{~mol} \cdot \mathrm{L}^{-1} \mathrm{~N}_{2}$-saturated PBS (pH 7.5) containing $1 \mathrm{mmol} \cdot \mathrm{L}^{-1} \mathrm{HQ}$ and $2 \mathrm{mmol} \cdot \mathrm{L}^{-1}$ $\mathrm{H}_{2} \mathrm{O}_{2}$. Chitosan/GCE electrode demonstrated a pair of well-defined redox peaks with potentials at about 0.14 and $-0.07 \mathrm{~V}$ which is characteristic of redox process of $\mathrm{HQ}$ and $\mathrm{H}_{2} \mathrm{O}_{2}{ }^{[30]}$. In comparison with the signal obtained from chitosan/GCE, modification of the GCE with MXene/chitosan resulted in signal enhanced of the redox peaks. Following HRP immobilization, both HRP@chitosan/ GCE and HRP@MXene/chitosan/GCE demonstrated further enhanced reduction peak with HRP@MXene/chitosan/ GCE showing highest increase in reduction peak's current

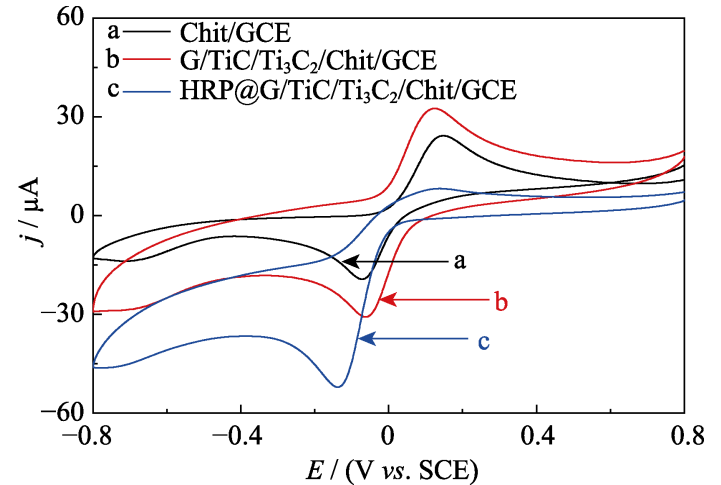

Fig. 4 CV curves of Chit/GCE (curve a, black line), MXene/ Chit/GCE (curve b, red line), HRP/Chit/GCE (curve c, pink line),HRP@MXene/Chit/GCE (curve d, blue line) electrodes cycled in $\mathrm{N}_{2}$-saturated $0.1 \mathrm{~mol} \cdot \mathrm{L}^{-1}$ PBS ( $\mathrm{pH} 7.5$ ) containing $1.0 \mathrm{mmol} \cdot \mathrm{L}^{-1}$ $\mathrm{HQ}$ and $2.0 \mathrm{mmol} \cdot \mathrm{L}^{-1} \mathrm{H}_{2} \mathrm{O}_{2}$ at a scanning rate of $50 \mathrm{mV} \cdot \mathrm{s}^{-1}$ (potential window: $-0.8-0.8 \mathrm{~V} v s$. SCE).

$(52 \mu \mathrm{A})$. Increase in the reduction peak current can be attributed to reduction process of $\mathrm{H}_{2} \mathrm{O}_{2}$ catalyzed by HRP at its reducing state $\left(\mathrm{HRP}_{\mathrm{RED}}\right)$ (Fig. 1). During this reduction process, the redox centre of $\mathrm{HRP}_{\mathrm{RED}}$ turned into its oxidizing state $\left(\mathrm{HRP}_{\mathrm{OX}}\right) . \mathrm{HRP}_{\mathrm{OX}}$ were then regenerated into $\mathrm{HRP}_{\mathrm{RED}}$ with the aid of HQ which was oxidized to form benzoquinone. Finally, benzoquinone exchanged electrons with the electrode to electrochemically produced $\mathrm{HQ}$. The redox processes of $\mathrm{H}_{2} \mathrm{O}_{2}$ and hydroquinone were in agreement with those previously reported findings ${ }^{[30]}$. The aforementioned findings showed HRP@MXene/chitosan/GCE biosensor can be used for electrochemical biosensing of $\mathrm{H}_{2} \mathrm{O}_{2}$ and MXene provided a favorable microenvironment to retain the bioactivity of HRP.

Fig. S2(A) shows the CV of HRP@MXene/chitosan/GCE obtained in $0.1 \mathrm{~mol} \cdot \mathrm{L}^{-1} \mathrm{~N}_{2}$-saturated PBS ( $\mathrm{pH} 7.5$ ) containing $1 \mathrm{mmol} \cdot \mathrm{L}^{-1} \mathrm{HQ}$ and $2 \mathrm{mmol} \cdot \mathrm{L}^{-1} \mathrm{H}_{2} \mathrm{O}_{2}$ at various scan rates. The redox peaks of HRP@MXene/chitosan/GCE increased linearly versus the square root of scanning rates from 20 to $500 \mathrm{mV} \cdot \mathrm{s}^{-1}$ (Fig. S2(B)). The electrochemical behaviors were in accordance with a diffusion-controlled process occurring at the surface of the biosensor ${ }^{[31]}$. Similar results for different electrodes with mediator were also reported ${ }^{[28,32]}$.

Based on aforementioned findings, PBS buffer's $\mathrm{pH}$ of 7.5 and MXene concentration of $5 \mathrm{mg} \cdot \mathrm{mL}^{-1}$ were used for fabrication of HRP@MXene/chitosan/GCE in the subsequent analysis.

Electrochemical biosensing of $\mathrm{H}_{2} \mathrm{O}_{2}$ by HRP@MXene/ chitosan/GCE was optimized in terms of electrolyte PBS buffer's $\mathrm{pH}(\mathrm{pH}$ 5.5-8.0) and concentration of MXene $\left(0.5-10 \mathrm{mg} \cdot \mathrm{mL}^{-1}\right)$. The $\mathrm{pH}$ value of the electrolyte is important for the performance of enzyme electrode as HRP activity is greatly affected by $\mathrm{pH}$. Fig. S3(A) shows that the peak current of HRP@MXene/chitosan/GCE 
increased from $\mathrm{pH} 5.5$ and reached maximum at $\mathrm{pH}$ 7.5. The value of $\mathrm{pH}$ was chosen for further study and was also in agreement with previous observations reported ${ }^{[33]}$. Fig. S3(B) shows the peak currents of cyclic voltammograms of HRP@MXene/chitosan/GCE fabricated with different concentration of MXene. Peak current of HRP@MXene/chitosan/GCE was the highest at $5 \mathrm{mg} \cdot \mathrm{mL}^{-1}$ MXene (MXene: HRP ratio IS $1: 1$ ). At this concentration of MXene, HRP was fully immobilized on the surface of MXene and the biosensor demonstrated most effective performance. In terms of DPV responses (Fig. S3(C)), negative shifts in peak potentials can be observed with increased $\mathrm{pH}$ value. This indcated that $\mathrm{H}^{+}$participated in the HRP catalyzed $\mathrm{H}_{2} \mathrm{O}_{2}$ reduction reaction to produce water. Peak potential was also affected by concentration of MXene with negative shift in peak potential and highest peak current can be observed at $5 \mathrm{mg} \cdot \mathrm{mL}^{-1}$ MXene (Fig. S3(D)).

\subsection{Electrochemical detection of $\mathrm{H}_{2} \mathrm{O}_{2}$ in spiked dried scallop and milk}

The current-time curve which is a potential-controlled electrochemical analysis method was used to build a calibration curve of amperometric response at a series of $\mathrm{H}_{2} \mathrm{O}_{2}$ concentration. Fig. 5(A) shows the amperometric response of HRP@MXene/chitosan/GCE following suc- cessive additions of $\mathrm{H}_{2} \mathrm{O}_{2}$ to PBS buffer (Potential $=-0.1 \mathrm{~V}$ ). The corresponding calibration curves of HRP@MXene/ chitosan/GCE biosensor were presented in Fig. 5(B), which was linear at two concentration ranges (5-190 and $\left.190-1650 \mu \mathrm{mol} \cdot \mathrm{L}^{-1} \mathrm{H}_{2} \mathrm{O}_{2}\right)$ with a linear regression equation of $Y=0.02644 X+0.55914\left(R^{2}=0.999\right)$ and $Y=0.01959 X$ $+1.84114\left(R^{2}=0.996\right)$. Moreover, the fabricated biosensor also showed very low detection limit of $0.74 \mu \mathrm{mol} \cdot \mathrm{L}^{-1}$. A comparison of linear range and detection limit for $\mathrm{H}_{2} \mathrm{O}_{2}$ with other $\mathrm{H}_{2} \mathrm{O}_{2}$ sensors reported in literature are summarized in Table S1. The data demonstrated that both the linear range and detection limit for $\mathrm{H}_{2} \mathrm{O}_{2}$ are comparable or even better than those detected using sensors recently reported. The excellent biosensing performance of HRP@MXene/chitosan/GCE can be ascribed to the unique vertical junction structure of the two dimensional MXene nanosheets which provided a suitable matrix for HRP immobilization and also platform for $\mathrm{H}_{2} \mathrm{O}_{2}$ and $\mathrm{HQ}$ redox reactions.

Present work used dried scallop and milk as representative of solid and liquid food system to explore the application of HRP@MXene/chitosan/GCE biosensor in detection of $\mathrm{H}_{2} \mathrm{O}_{2}$ in food samples. Fig. 5(C, D) shows the amperometric response of HRP@MXene/chitosan/GCE following additions of solutions extracted from milk and
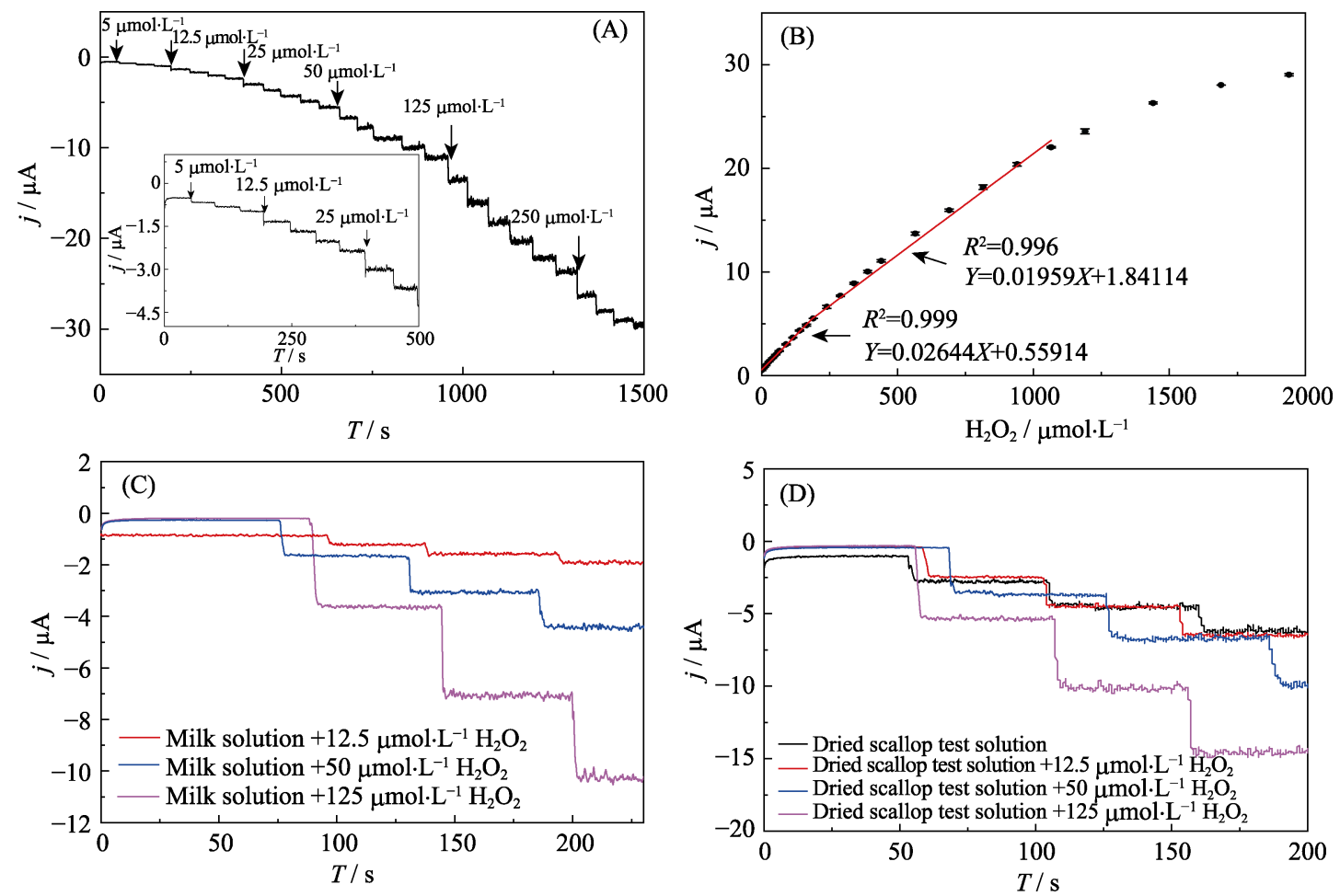

Fig. 5 Amperometric responses of HRP@MXene/Chit/ GCE at $-0.1 \mathrm{~V}$ upon successive additions of $\mathrm{H}_{2} \mathrm{O}_{2}$ in a stirred $0.1 \mathrm{~mol} \cdot \mathrm{L}^{-1}$ PBS (pH 7.5) (A); Calibration curve of amperometric responses at different $\mathrm{H}_{2} \mathrm{O}_{2}$ concentrations (B);

Amperometric responses of HRP@MXene/Chit/ GCE at $-0.1 \mathrm{~V}$ upon successive additions of solutions extracted from milk sample (C) and dried scallop (D) spiked with different $\mathrm{H}_{2} \mathrm{O}_{2}$ under stirred $0.1 \mathrm{~mol} \cdot \mathrm{L}^{-1} \mathrm{PBS}(\mathrm{pH}$ 7.5) 
Table 1 Detection of hydrogen peroxide in real food sample

\begin{tabular}{ccccc}
\hline Sample & $\begin{array}{c}\text { Added } \mathrm{H}_{2} \mathrm{O}_{2} / \\
\left(\mu \mathrm{mol} \cdot \mathrm{L}^{-1}\right)\end{array}$ & $\begin{array}{c}\text { Found } \mathrm{H}_{2} \mathrm{O}_{2} / \\
\left(\mu \mathrm{mol} \cdot \mathrm{L}^{-1}\right)\end{array}$ & $\begin{array}{c}\text { Recovery } \\
/ \%\end{array}$ & $\begin{array}{c}\mathrm{RSD} \\
/ \%\end{array}$ \\
\hline Milk & 12.5 & 13.037 & 104.30 & 5.88 \\
Milk & 50 & 52.57 & 105.14 & 1.12 \\
Milk & 125 & 136.5 & 109.20 & 3.33 \\
Dried scallop & 0 & 66.56 & - & - \\
Dried scallop & 12.5 & 77.84 & 90.24 & 6.97 \\
Dried scallop & 50 & 120.08 & 107.04 & 1.46 \\
Dried scallop & 125 & 189.11 & 98.04 & 8.39 \\
\hline
\end{tabular}

dried scallop with different concentration of $\mathrm{H}_{2} \mathrm{O}_{2}$. The curves show HRP@MXene/chitosan/GCE is a rapid and sensitive method to detect $\mathrm{H}_{2} \mathrm{O}_{2}$ at different concentraitons. The recovery of $\mathrm{H}_{2} \mathrm{O}_{2}$ in food samples at different concentrations ranged from $(90.24 \pm 6.97) \%$ to $(109.20 \pm 3.33) \%$ (Table 1). The results indicated that the fabricated biosensor is a reliable tool for detection of residual $\mathrm{H}_{2} \mathrm{O}_{2}$ in food samples.

\subsection{Selectivity and stability of the HRP@ MXene/chitosan/GCE}

The anti-interference performance of HRP@MXene/ chitosan/GCE biosensor was evaluated by detecting $100 \mu \mathrm{mol} \cdot \mathrm{L}^{-1} \mathrm{H}_{2} \mathrm{O}_{2}$ in the presence of the same concentration of ascorbic acid, glucose and uric acid as interfering substances. As shown in Fig. S4(A), there were no noticeable amperometric responses from glucose and uric acid. However, amperometric responses can be detected by ascorbic acid $\left(34 \% \mathrm{H}_{2} \mathrm{O}_{2}\right)$ indicating ascorbic acid has the capability to participate in the redox process of HQ and $\mathrm{H}_{2} \mathrm{O}_{2}$; hence, interfering with the measurement of $\mathrm{H}_{2} \mathrm{O}_{2}$.

HRP@MXene/chitosan/GCE demonstrated good storage and operational stability. When stored in $0.05 \mathrm{~mol} \cdot \mathrm{L}^{-1}$ PBS (pH 7.5) at $4{ }^{\circ} \mathrm{C}, \mathrm{HRP} @ \mathrm{MXene} /$ chitosan/GCE was able to retain $84.8 \%$ of its initial response to $\mathrm{H}_{2} \mathrm{O}_{2}$ after a period of $10 \mathrm{~d}$ (Fig. S4(B)). This indicated that the vertical junction structure of the MXene (Graphite/ $\mathrm{TiC} / \mathrm{Ti}_{3} \mathrm{C}_{2}$ ) were able to act as an effective and stable platform for entrapment enzyme HRP.

\section{Conclusion}

In summary, we have explored a new type of supporting material for immobilizing HRP and fabricated an electrochemical $\mathrm{H}_{2} \mathrm{O}_{2}$ biosensor for in situ detection of $\mathrm{H}_{2} \mathrm{O}_{2}$ in food products. The synthesized MXene exhibited large specific area, biocompatibility, excellent electronic conductivity, and good dispersion in aqueous phase. HRP enzymes molecules immobilized on MXene/chitosan/GCE electrode showed good electrochemical behaviors and electrocatalytic activity toward reduction of $\mathrm{H}_{2} \mathrm{O}_{2}$. The fabricated HRP@MXene/chitosan/GCE biosensor exhibited a wide linear range from $5 \mu \mathrm{mol} \cdot \mathrm{L}^{-1}$ to $1.650 \mathrm{mmol} \cdot \mathrm{L}^{-1}$ and a low detection limit of $0.74 \mu \mathrm{mol} \cdot \mathrm{L}^{-1}$ with long-term stability, good reproducibility and high selectivity. The fabricated biosensor has also been successfully employed for detection of trace level of $\mathrm{H}_{2} \mathrm{O}_{2}$ in real food products (both solid and liquid food). The study provides a good concept for construction of electrochemical $\mathrm{H}_{2} \mathrm{O}_{2}$ biosensor based on MXene.

\section{Supporting materials}

Supporting materials related to this article can be found at https://doi.org/10.15541/jim20190139

\section{References:}

[1] ZHANG R, CHEN W. Recent advances in graphene-based nanomaterials for fabricating electrochemical hydrogen peroxide sensors. Biosensors \& bioelectronics, 2017, 89(Pt1): 249-268.

[2] ADMINISTRATION F D. Code of Federal Regulations, 21CFR184.1366 2018.

[3] DAI H, LU W, ZUO X, et al. A novel biosensor based on boronic acid functionalized metal-organic frameworks for the determination of hydrogen peroxide released from living cells. Biosensors \& Bioelectronics, 2017, 95: 131-137.

[4] WANG Y, ZHAO K J, ZHANG Z Q, et al. Simple approach to fabricate a highly sensitive $\mathrm{H}_{2} \mathrm{O}_{2}$ biosensor by one-step of graphene oxide and horseradish peroxidase co-immobilized glassy carbon electrode. International Journal of Electrochemical Science, 2018, 13(3): 2921-2933.

[5] CHANG M C Y, PRALlE A, ISACOFF E Y, et al. A selective, cell-permeable optical probe for hydrogen peroxide in living cells. Journal of the American Chemical Society, 2004, 126(47): 15392-15393.

[6] SHARMA M, KOTHARI C, SHERIKAR O, et al. Concurrent estimation of amlodipine besylate, hydrochlorothiazide and valsartan by RP-HPLC, HPTLC and UV-Spectrophotometry. Journal of Chromatographic Science, 2014, 52(1): 27-35.

[7] MATSUBARA C, KAWAMOTO N, TAKAMURA K. Oxo[5, 10, 15, 20-tetra(4-pyridyl)porphyrinato]titanium(IV): an ultra-high sensitivity spectrophotometric reagent for hydrogen peroxide. Analyst, 1992, 117(11): 1781-1784.

[8] ZHOU K, ZHU Y, YANG X, et al. A novel hydrogen peroxide biosensor based on Au-graphene-HRP-chitosan biocomposites. Electrochimica Acta, 2010, 55(9): 3055-3060.

[9] THENMOZHI K, NARAYANAN S S. Horseradish peroxidase and toluidine blue covalently immobilized leak-free Sol-Gel composite biosensor for hydrogen peroxide. Materials Science \& Engineering C, Materials for Biological Applications, 2017, 70(Pt1): 223-230.

[10] MA B K, CHEONG L Z, WENG X C, et al. Lipase@ZIF-8 nanoparticles-based biosensor for direct and sensitive detection of methyl parathion. Electrochimica Acta, 2018, 283: 509-516.

[11] JOS'E I, REYES-DE-CORCUERA H E O, GARC'1A-TORRES A R. Stability and Stabilization of Enzyme Biosensors: The Key to Successful Application and Commercialization. 2018.

[12] LIU Y, LIU X, GUO Z, et al. Horseradish peroxidase supported on porous graphene as a novel sensing platform for detection of hydrogen peroxide in living cells sensitively. Biosensors \& Bioelectronics, 2017, 87: 101-107.

[13] ZHENG J, DIAO J, JIN Y, et al. An inkjet printed $\mathrm{Ti}_{3} \mathrm{C}_{2}$-GO electrode for the electrochemical sensing of hydrogen peroxide. Jour- 
nal of The Electrochemical Society, 2018, 165(5): B227- B231.

[14] ZHAO M Q, XIE X, REN C E, et al. Hollow mxene spheres and 3D macroporous mxene frameworks for Na-ion storage. Advanced Materials, 2017, 29(37): 1702410.

[15] ZHOU J, ZHA X, ZHOU X, et al. Synthesis and electrochemical properties of two-dimensional hafnium carbide. ACS Nano, 2017, 11(4): 3841-3850.

[16] XU B, ZHU M, ZHANG W, et al. Ultrathin MXene-micropatternbased field-effect transistor for probing neural activity. Advanced Materials, 2016, 28(17): 3333-3339.

[17] LORENCOVA L, BERTOK T, DOSEKOVA E, et al. Electrochemical performance of $\mathrm{Ti}_{3} \mathrm{C}_{2} \mathrm{~T}_{x}$ MXene in aqueous media: towards ultrasensitive $\mathrm{H}_{2} \mathrm{O}_{2}$ sensing. Electrochimica Acta, 2017, 235: 471-479.

[18] LORENCOVA L, BERTOK T, FILIP J, et al. Highly stable $\mathrm{Ti}_{3} \mathrm{C}_{2} \mathrm{~T}_{x}$ (MXene)/Pt nanoparticles-modified glassy carbon electrode for $\mathrm{H}_{2} \mathrm{O}_{2}$ and small molecules sensing applications. Sensors and Actuators B: Chemical, 2018, 263: 360-368.

[19] WANG F, YANG C, DUAN M, et al. $\mathrm{TiO}_{2}$ nanoparticle modified organ-like $\mathrm{Ti}_{3} \mathrm{C}_{2}$ MXene nanocomposite encapsulating hemoglobin for a mediator-free biosensor with excellent performances. Biosensors and Bioelectronics, 2015, 74: 1022-1028.

[20] LIU H, DUAN C, YANG C, et al. A novel nitrite biosensor based on the direct electrochemistry of hemoglobin immobilized on MXene- $\mathrm{Ti}_{3} \mathrm{C}_{2}$. Sensors and Actuators B: Chemical, 2015, 218: 60-66.

[21] RAKHI R B, NAYAK P, XIA C, et al. Novel amperometric glucose biosensor based on MXene nanocomposite. Scientific Reports, 2016, 6: 36422.

[22] VEITCH N C. Horseradish peroxidase: a modern view of a classic enzyme. Phytochemistry, 2004, 65(3): 249-259.

[23] REN Q Q, WU J, ZHANG W C, et al. Real-time in vitro detection of cellular $\mathrm{H}_{2} \mathrm{O}_{2}$ under camptothecin stress using horseradish peroxidase, ionic liquid, and carbon nanotube-modified carbon fiber ultramicroelectrode. Sensors and Actuators B: Chemical, 2017,
245: 615-621.

[24] LI M, HAN M, ZHOU J, et al. Novel scale-like structures of graphite $/ \mathrm{TiC} / \mathrm{Ti}_{3} / \mathrm{C}_{2}$ hybrids for electromagnetic absorption. Advanced Electronic Materials, 2018, 4(5): 1700617.

[25] SHAN C, YANG H, HAN D, et al. Graphene/AuNPs/chitosan nanocomposites film for glucose biosensing. Biosensors \& Bioelectronics, 2010, 25(5): 1070-1074.

[26] WANG F, YANG C, DUAN C, et al. An organ-like titanium carbide material (MXene) with multilayer structure encapsulating hemoglobin for a mediator-free biosensor. Journal of The Electrochemical Society, 2014, 162(1): B16-B21.

[27] KANG X B, PANG G C, LIANG X Y, et al. Study on a hydrogen peroxide biosensor based on horseradish peroxidase/GNPs-thionine/ chitosan. Electrochimica Acta, 2012, 62: 327-334.

[28] KOPOSOVA E, LIU X, KISNER A, et al. Bioelectrochemical systems with oleylamine-stabilized gold nanostructures and horseradish peroxidase for hydrogen peroxide sensor. Biosensors \& Bioelectronics, 2014, 57: 54-58.

[29] YANG S, DING S, LI L, et al. One-step preparation of direct electrochemistry HRP biosensor via electrodeposition. Journal of The Electrochemical Society, 2017, 164(13): B710-B714.

[30] CHEN W, YANG W, LU Y, et al. Encapsulation of enzyme into mesoporous cages of metal-organic frameworks for the development of highly stable electrochemical biosensors. Analytical Methods, 2017, 9(21): 3213-3220.

[31] BARD A J, FAULKNER L R, LEDDY J, et al. Electrochemical methods: Fundamentals and Applications. Wiley New York, 1980.

[32] SONG H, NI Y, KOKOT S. Investigations of an electrochemical platform based on the layered $\mathrm{MoS}_{2}$-graphene and horseradish peroxidase nanocomposite for direct electrochemistry and electrocatalysis. Biosensors \& Bioelectronics, 2014, 56: 137-143.

[33] MART N M, SALAZAR P, VILLALONGA R, et al. Preparation of core-shell $\mathrm{Fe}_{3} \mathrm{O}_{4} @$ poly(dopamine) magnetic nanoparticles for biosensor construction. J. Mater. Chem. B, 2014, 2(6): 739-746.

\title{
酶-二维 MXene 复合材料的制备及其 电化学检测 $\mathrm{H}_{2} \mathrm{O}_{2}$ 的应用
}

\section{马保凯 ${ }^{1,2,3}$, 李 勉 ${ }^{3}$, 张绫芷 ${ }^{2}$, 翁新楚 ${ }^{1}$, 沈 彩 $^{3}$, 黄 庆 $^{3}$}

(1. 上海大学 生命科学学院, 上海 200444; 2. 宁波大学 食品与药学学院, 宁波 315211 ; 3 . 中国科学院 宁波材料 技术与工程研究所, 宁波 315201)

\begin{abstract}
摘 要: 本研究合成了具有垂直栅栏结构的二维 MXene 材料, 与辣根过氧化物酶进行固定, 构筑了过氧化氢电化学 酶传感器。合成的 MXene 纳米栅栏具有大的比表面积, 优良的电子传导特性和在水溶液中的良好分散特性; 固定 化在酶电极上的辣根过氧化物酶分子表现出了优良的过氧化氢催化效果。结果表明 HRP@MXene/chitosan/GCE 酶 电化学传感器在过氧化氢浓度为 $5 \sim 1650 \mu \mathrm{mol} / \mathrm{L}$ 范围内表现出很好的线性关系, 最低检测限为 $0.74 \mu \mathrm{mol} / \mathrm{L}$, 且具有 很好的操作稳定性，该生物传感器被成功地应用于固态与液态食品中过氧化氢残留检测。
\end{abstract}

关 键 词: 辣根过氧化物酶; MXene 纳米片; 生物传感器; 过氧化氢

\section{中图分类号: TS207文献标识码: A}




\title{
Supporting information:
}

\section{Enzyme-MXene Nanosheets: Fabrication and Application in Electrochemical Detection of $\mathrm{H}_{2} \mathrm{O}_{2}$}

\author{
MA Bao-Kai ${ }^{1,2,3}$, LI Mian ${ }^{3}$, CHEONG Ling-Zhi ${ }^{2}$, WENG Xin-Chu ${ }^{1}$, SHEN Cai ${ }^{3}$, HUANG Qing ${ }^{3}$
}

(1. School of Life and Sciences, Shanghai University, Shanghai, 200444, China; 2. Department of Food Science and Engineering, College of Food and Pharmaceutical Sciences, Ningbo University, Ningbo 315211, China; 3. Institute of Materials Technology \& Engineering, Chinese Academy of Sciences, Ningbo, 315201, China)
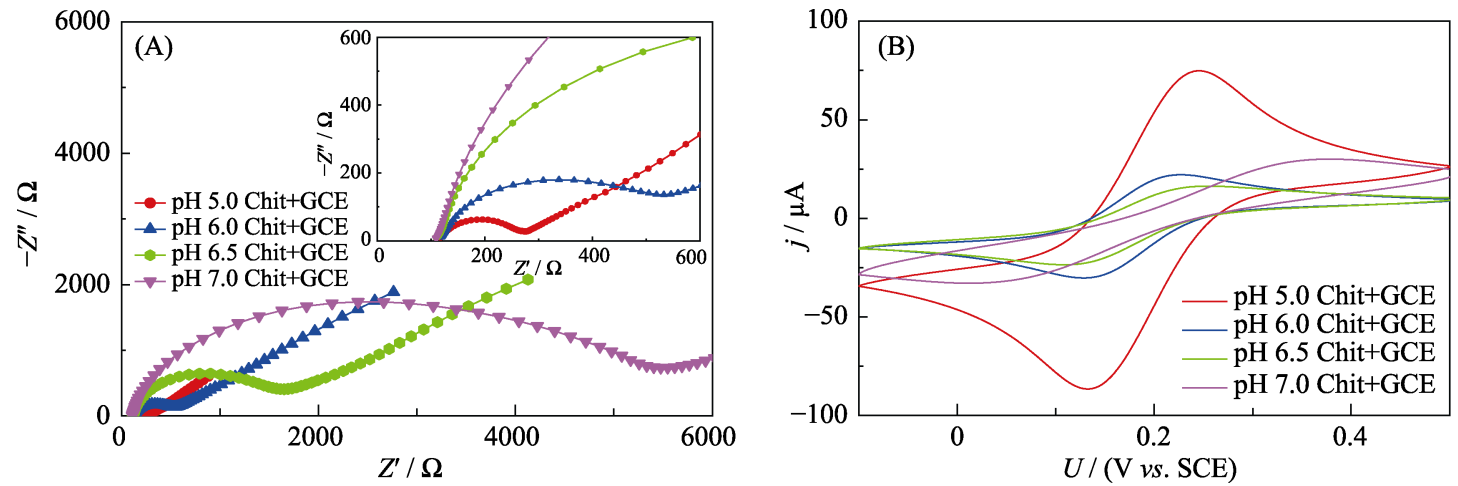

Fig. S1 EIS of various electrodes in $0.1 \mathrm{~mol} \cdot \mathrm{L}^{-1} \mathrm{KCL}$ aqueous solution containing $5 \mathrm{mmol} \cdot \mathrm{L}^{-1}\left[\mathrm{Fe}(\mathrm{CN})_{6}\right]^{3-/ 4-}$ : Chit (pH 5.0)/GCE (curve b, red line), Chit ( $\mathrm{pH}$ 6.0)/GCE (curve c, blue line), Chit (pH 6.5)/GCE (curve d, green line),

Chit (pH 7.0)/GCE (curve e, pink line) (A); CV curves of Chit (pH 5.0)/GCE (curve b, red line), Chit (pH 6.0)/GCE (curve c, blue line), Chit (pH 6.5)/GCE (curve d, green line), Chit (pH 7.0)/GCE (curve e, pink line) electrodes cycled in $0.1 \mathrm{~mol} \cdot \mathrm{L}^{-1} \mathrm{KCL}$ aqueous solution containing $5 \mathrm{mmol} \cdot \mathrm{L}^{-1}\left[\mathrm{Fe}(\mathrm{CN})_{6}\right]^{3-/ 4-}$ : (potential window: $-0.1-0.5 \mathrm{~V} v s$. SCE) (B)
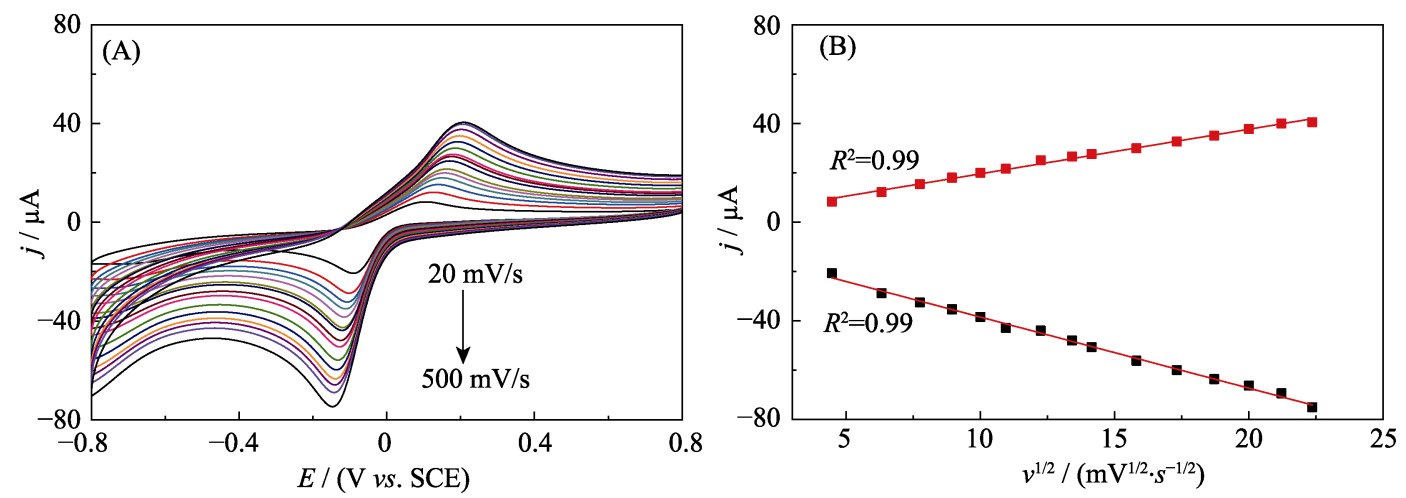

Fig. S2 CV curves of HRP@MXene/Chit/GCE electrodes cycled in $\mathrm{N}_{2}$-saturated $0.1 \mathrm{~mol} \cdot \mathrm{L}^{-1} \mathrm{PBS}(\mathrm{pH} 7.5)$ containing $1.0 \mathrm{mmol} \cdot \mathrm{L}^{-1} \mathrm{HQ}$ and $2.0 \mathrm{mmol} \cdot \mathrm{L}^{-1} \mathrm{H}_{2} \mathrm{O}_{2}$ at different scanning rates $\left(20-500 \mathrm{mV} \cdot \mathrm{s}^{-1}\right)$ (A); Plot of cathodic and anodic peak current for HRP@MXene/Chit/GCE versus scanning rate (B); Inset: Plots of anodic peak potential and cathodic peak potential for HRP@MXene/Chit/GCE electrode versus the logarithm of scanning rate
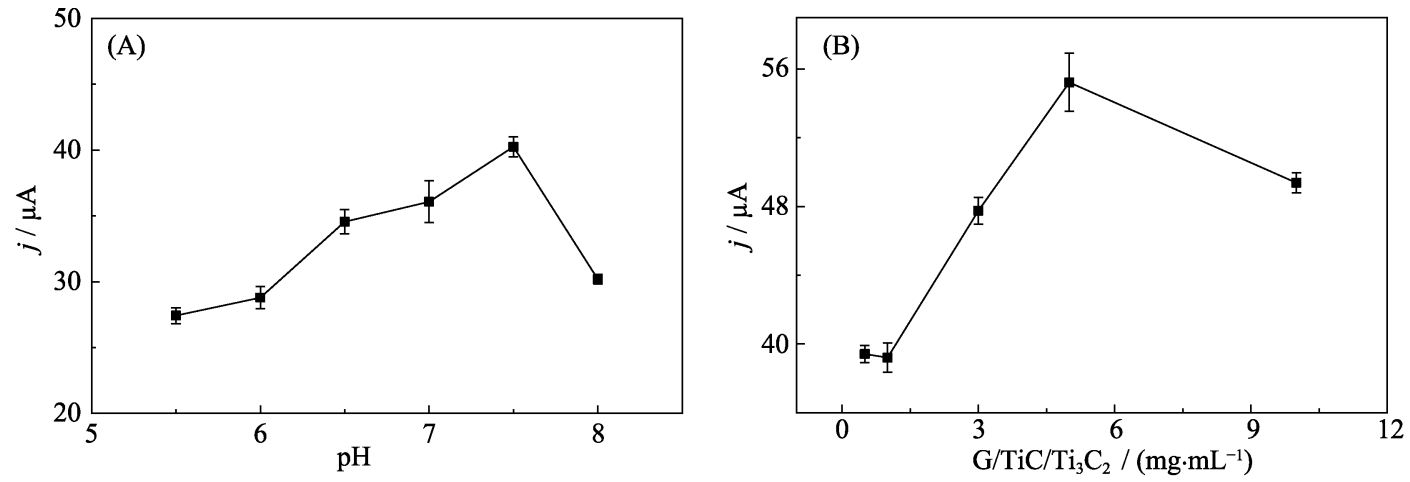

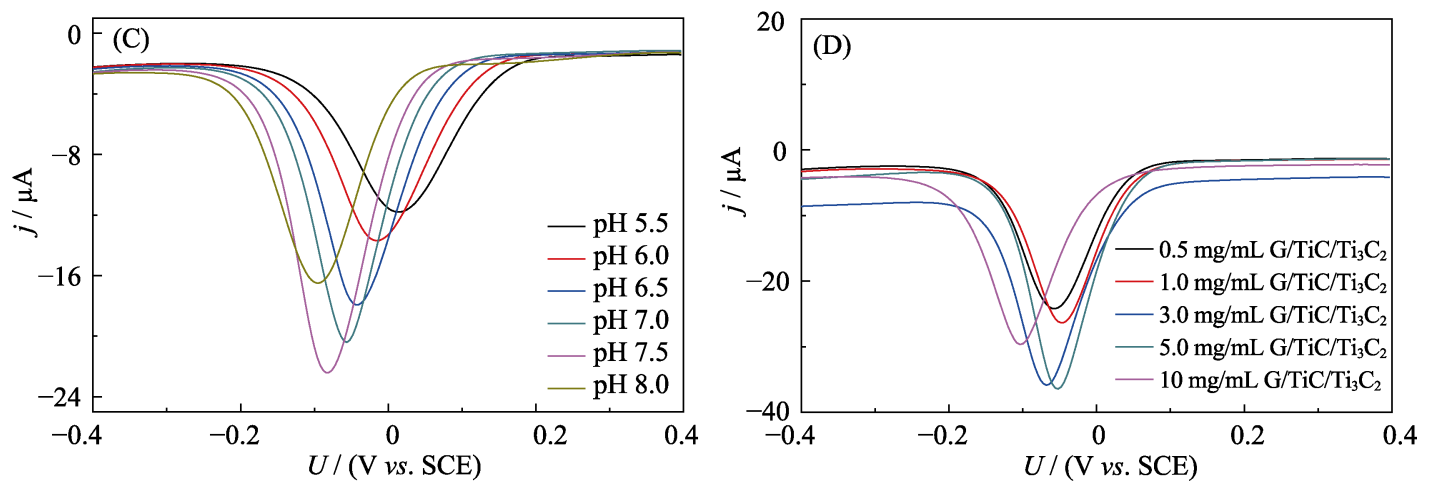

Fig. S3 Effects of PBS buffer's pH (A) and concentration of MXene (B) on the cathodic peak current of enzyme biosensor cycled in $\mathrm{N}_{2}$-saturated $0.1 \mathrm{~mol} \cdot \mathrm{L}^{-1} \mathrm{PBS}\left(\mathrm{pH} 7.5\right.$ ) containing $1.0 \mathrm{mmol} \cdot \mathrm{L}^{-1} \mathrm{HQ}$ and $2.0 \mathrm{mmol} \cdot \mathrm{L}^{-1} \mathrm{H}_{2} \mathrm{O}_{2}$; Effects of PBS buffer's pH (C) and concentration of MXene (D) on the DPV response of enzyme biosensor cycled in $\mathrm{N}_{2}$-saturated $0.1 \mathrm{~mol} \cdot \mathrm{L}^{-1} \mathrm{PBS}(\mathrm{pH} 7.5)$ containing $1.0 \mathrm{mmol} \cdot \mathrm{L}^{-1} \mathrm{HQ}$ and $2.0 \mathrm{mmol} \cdot \mathrm{L}^{-1} \mathrm{H}_{2} \mathrm{O}_{2}$
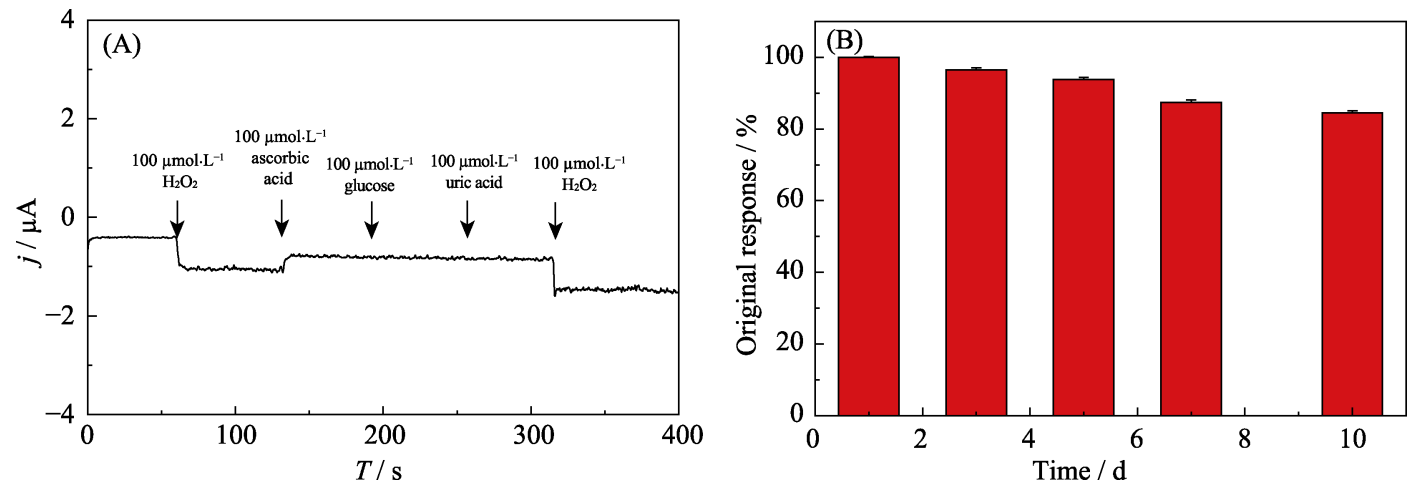

Fig. S4 Amperometric response of HRP@MXene/Chit/GCE in $0.1 \mathrm{~mol} \cdot \mathrm{L}^{-1} \mathrm{pH} 7.5 \mathrm{PBS}$ containing $100 \mu \mathrm{mol} \cdot \mathrm{L}^{-1}$ of ascorbic acid, glucose, uric acid and $\mathrm{H}_{2} \mathrm{O}_{2}$ (Applied potential: $-0.1 \mathrm{~V}$ ) (A); Reduction peak currents of HRP@MXene/Chit/GCE stored in $50 \mathrm{mmol} \cdot \mathrm{L}^{-1} \mathrm{PBS}(\mathrm{pH} 7.5)$ at 4 for $10 \mathrm{~d}(\mathrm{~B})$

Table S1 Comparison of the performance of present work with other published electrodes for hydrogen peroxide detection

\begin{tabular}{|c|c|c|c|}
\hline Electrode & Linear range $/\left(\mu \mathrm{mol} \cdot \mathrm{L}^{-1}\right)$ & $\mathrm{LOD} /\left(\mu \mathrm{mol} \cdot \mathrm{L}^{-1}\right)$ & Ref. \\
\hline HRP-CTAB-Au/GCE & $0.50-105$ & 0.23 & {$[1]$} \\
\hline $\mathrm{HRP} / \mathrm{GO} / \mathrm{GCE}$ & $0.002-0.5$ & 1.6 & [2] \\
\hline $\mathrm{HRP} / \mathrm{TB} / \mathrm{CCB}$ & $0.429-455$ & 0.17 & [3] \\
\hline HRP-BMIM·BF4/SWCNTs & 0.49 to 10.2 & 0.13 & [4] \\
\hline $\mathrm{HRP} / \mathrm{PGN} / \mathrm{GCE}$ & $2.77-835$ & $2.67 \times 10^{-4}$ & {$[5]$} \\
\hline Hb-MXene-GO/Au foil & $2-1 \times 10^{3}$ & 1.95 & {$[6]$} \\
\hline MXene/GCE & - & $0.7 \times 10^{-3}$ & [7] \\
\hline Hb-naf-MXene/GCE & $0.1-260$ & 0.02 & [8] \\
\hline $\mathrm{TiO}_{2}$-Hb-naf-MXene/GCE & $0.1-380$ & $1.4 \times 10^{-2}$ & [9] \\
\hline HRP@MXene/Chitosan/GCE & $5-1.65 \times 10^{3}$ & 0.74 & This work \\
\hline
\end{tabular}

* HRP: Horseradish Peroxidase; CTAB: cetyltrimethylammonium bromide; GO: graphene oxide; TB: Toluidine blue; CCB: ceramic composite biosensor; BMIM-BF4: 1-butyl-3-methylimidazolium tetrafluoroborat; SWCNTs: Single-walled carbon nanotubes; PGN: porous grapheme; $\mathrm{Hb}$ : hemoglobin; naf: nafion

\section{References:}

[1] YANG S, DING S, LI L, et al. One-step preparation of direct electrochemistry HRP biosensor via electrodeposition. Journal of The Electrochemical Society, 2017, 164(13): B710-B714.

[2] WANG Y, ZHAO K J, ZHANG Z Q, et al. Simple approach to fab- ricate a highly sensitive $\mathrm{H}_{2} \mathrm{O}_{2}$ biosensor by one-step of graphene oxide and horseradish peroxidase co-immobilized glassy carbon electrode. International Journal of Electrochemical Science, 2018, 13(3): 2921-2933.

[3] THENMOZHI K, NARAYANAN S S. Horseradish peroxidase and toluidine blue covalently immobilized leak-free Sol-Gel composite biosensor for hydrogen peroxide. Materials Science \& Engineering 
C, Materials for Biological Applications, 2017, 70(Pt 1): 223-230.

[4] REN Q Q, WU J, ZHANG W C, et al. Real-time in vitro detection of cellular $\mathrm{H}_{2} \mathrm{O}_{2}$ under camptothecin stress using horseradish peroxidase, ionic liquid, and carbon nanotube-modified carbon fiber ultramicroelectrode. Sensors and Actuators B: Chemical, 2017, 245: 615-621.

[5] LIU Y, LIU X, GUO Z, et al. Horseradish peroxidase supported on porous graphene as a novel sensing platform for detection of hydrogen peroxide in living cells sensitively. Biosensors \& Bioelectronics, 2017, 87: 101-107.

[6] ZHENG J, DIAO J, JIN Y, et al. An inkjet printed $\mathrm{Ti}_{3} \mathrm{C}_{2}$-GO electrode for the electrochemical sensing of hydrogen peroxide. Journal of The Electrochemical Society, 2018, 165(5): B227-B231.

[7] LORENCOVA L, BERTOK T, DOSEKOVA E, et al. Electrochemical performance of $\mathrm{Ti}_{3} \mathrm{C}_{2} \mathrm{~T}_{x}$ MXene in aqueous media: towards ultrasensitive $\mathrm{H}_{2} \mathrm{O}_{2}$ sensing. Electrochimica Acta, 2017, 235: 471-479.

[8] WANG F, YANG C, DUAN C, et al. An organ-like titanium carbide material (MXene) with multilayer structure encapsulating hemoglobin for a mediator- free biosensor. Journal of The Electrochemical Society, 2014, 162(1): B16-B21.

[9] WANG F, YANG C, DUAN M, et al. $\mathrm{TiO}_{2}$ nanoparticle modified organ-like $\mathrm{Ti}_{3} \mathrm{C}_{2}$ MXene nanocomposite encapsulating hemoglobin for a mediator-free biosensor with excellent performances. Biosensors and Bioelectronics, 2015, 74: 1022-1028. 